\title{
Coral community composition and reef development at the Similan Islands, Andaman Sea, in response to strong environmental variations
}

\author{
Gertraud M. Schmidt ${ }^{1, *}$, Niphon Phongsuwan ${ }^{2}$, Carin Jantzen $^{1}$, Cornelia Roder ${ }^{3}$, \\ Somkiat Khokiattiwong ${ }^{2}$, Claudio Richter ${ }^{1}$
}

\author{
${ }^{1}$ Alfred Wegener Institute for Polar and Marine Research, Am Alten Hafen 26, 27568 Bremerhaven, Germany \\ ${ }^{2}$ Phuket Marine Biological Center, 51 Sakdidet Road, 83000 Phuket, Thailand \\ ${ }^{3} 4700$ King Abdullah University of Science and Technology, Thuwal 23955-6900, Kingdom of Saudi Arabia
}

\begin{abstract}
The Similan Islands, a Thai archipelago in the Andaman Sea located near the shelf break, are subjected to frequent (up to several events per hour) and abrupt changes in physicochemical conditions, particularly during the dry season (NE monsoon, January through April) and to an intense monsoon season with strong surface wave action (May to October). The exposed west slopes of the islands feature more coral species, but lack a carbonate reef framework. By contrast, the sheltered east sides show a complex reef framework dominated by massive Porites. Our results suggest that the sudden changes in temperature, $\mathrm{pH}$ and nutrients (drops of up to $10^{\circ} \mathrm{C}$ and $0.6 \mathrm{U}$ and increases of up to $9.4 \mu \mathrm{mol} \mathrm{NO} \mathrm{N}^{-1}$, respectively) due to pulsed upwelling events may rival the importance of surface waves and storms in shaping coral distribution and reef development.
\end{abstract}

KEY WORDS: Benthic-pelagic coupling · Coral community · Similan Islands · Andaman Sea · Upwelling $\cdot$ Internal waves

Resale or republication not permitted without written consent of the publisher

\section{INTRODUCTION}

Coral reefs are highly diverse and productive benthic ecosystems thriving in shallow, clear, warm, nutrient-poor, tropical waters (Veron 2000). Many reefs, however, are subjected to natural disturbances that affect hydrodynamics, light, temperature, nutrients and $\mathrm{pH}$ on various scales, e.g. monsoon-driven rainfall, mixing by storms and upwelling of cold, deep waters (Leichter et al. 1996). Surface gravity waves can strongly affect coral morphologies and reef development in exposed areas (Storlazzi et al. 2001). Internal waves have been shown to play an important role in the cross-shore exchange of nutrients, larvae and particulate food (Pineda 1991) and can be a source of nutrition for coral reefs (Leichter et al. 2003, Wolanski et al. 2004). However, when up- welling is strong, positive fertilizing effects may be counteracted by the negative effects of low temperature, low $\mathrm{pH}$ and high nutrient loads favouring algal rather than coral growth (McCook et al. 2001).

Reef growth is commonly most vigorous on the exposed offshore (or windward) side of an island (Veron 2000). Along the offshore islands in the Andaman Sea, however, satellite images (www.reefgis.reefbase.org) and monitoring studies (Phongsuwan et al. 2008) suggest that reef development is restricted to the sheltered east sides, while the west sides appear to be devoid of reef formations (Fig. 1).

The Andaman Sea features 2 major climatic and oceanographic phenomena: a strong SW monsoon from May to October, with strong swell and heavy rain (Wu \& Zhang 1998), and the occurrence of largeamplitude internal waves (LAIW) of $>60 \mathrm{~m}$ amplitude 


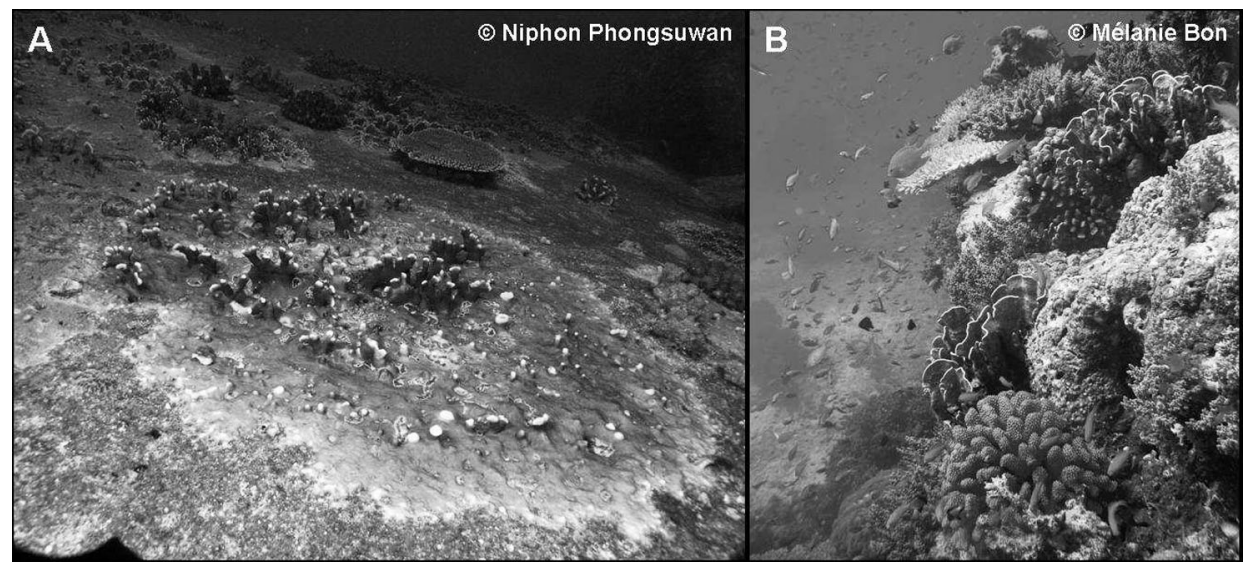

Fig. 1. Typical substrate conditions at about $12 \mathrm{~m}$ depth on the (A) west (W 4.1) and (B) east (E 7.1) side of the Similan Islands. See Fig. 2 for site locations

(Osborne \& Burch 1980, Jackson 2004) generated by tidal currents across the shallow ridges of the Andaman-Nicobar island arc and the reefs NW of Sumatra (Jackson 2004). The LAIWs travel as waves of depression in packets of 5 to 8 waves eastward across the deep Andaman basin at speeds of $2 \mathrm{~m} \mathrm{~s}^{-1}$ (Osborne \& Burch 1980) and are observable as rip bands on the ocean surface (Jackson 2004). Near the continental shelf break, the rip bands align with the isobaths and proceed in water shallower than $90 \mathrm{~m}$ (Jackson 2004), suggesting transformation into waves of elevation, breaking and generation of turbulent bores spilling onto the shelf (Vlasenko \& Hutter 2002). The resulting diapycnal mixing was shown to enhance pelagic production near the shelf break (Jackson 2004, Nielsen et al. 2004) in the swash zone of breaking solitons (Vlasenko \& Hutter 2002, Jackson 2004). The further transport of cold, deep waters due to LAIW up to shallow shelf areas, however, has not been proven yet. But 2 recent investigations at the Similan Islands, an offshore archipelago in the Andaman Sea located near the shelf break, found strong-pulsed upwelling at the exposed western side of the islands (Roder et al. 2010, 2011), suggesting that those LAIW may reach the island chain. These studies showed differences in the nutritional status of corals growing on the exposed west and sheltered east sides during a period of intense, pulsed upwelling.

This pulsed upwelling might be an important factor affecting not only the physiology of the corals but also the ecology of the coral communities. Low temperatures have been shown to limit reef development (Kleypas et al. 1999) and may select for species tolerant to low temperatures in areas subjected to upwelling of cold water (Brown 1997). Because upwelled waters can be low in oxygen (Levin et al. 1991) and pH (Levitus \& O'Brian 1998), they may select for corals adapted to cope with large fluctuations in these parameters. Further corals may benefit from enhanced nutrient supply due to increasing zooxanthellae densities (Muscatine et al. 1989, Ferrier-Pagès et al. 2001) and photosynthetic efficiency (Muscatine et al. 1989). But higher nutrient concentrations also favour the growth of competitively superior macroalgae (McCook et al. 2001) and enhance bioerosion (Chazottes et al. 2002). Tropical shallow platforms subjected to intense (wind-driven) upwelling have thus been shown to be devoid of coral reefs (Hallock \& Schlager 1986), but moderate and/or intermittent upwelling may allow for moderate to extensive reef development (Andrews \& Gentien 1982).

Nevertheless, it cannot be ruled out that physical forcing due to storms, mainly during the monsoon season, or caused by tsunamis, impacts reef development on the exposed western sides of these islands as well (Allen \& Stone 2005); although the recent tsunami in 2004 showed only moderate impact on Andaman Sea offshore coral reefs (Allen \& Stone 2005 , Plathong 2005), with $<13 \%$ of the reefs significantly damaged, and this damage affecting mostly the narrow north and south passages between islands and not the broad west island faces.

The present study explores the coral abundance and diversity in coral communities of the Similan Islands subjected to marked differences in temperature fluctuations and monsoonal storm exposure. We propose that the pulsed fluctuations due to upwelled waters and the impact of surface waves differentially affect shallow $(\sim 7 \mathrm{~m})$ and deep $(\sim 20 \mathrm{~m})$, west and east coral communities and carbonate framework development. This was tested by comparing coral community composition, cover and framework development 
on the west, east, shallow and deep faces of the islands and relating the biological findings to the physico-chemical characteristics of these habitats.

\section{MATERIALS AND METHODS}

\section{Study area}

The Similan Islands in the Andaman Sea, Thailand, are located about $60 \mathrm{~km}$ west of the Thai coast and $400 \mathrm{~km}$ east of the Andaman-Nicobar Islands. The 9

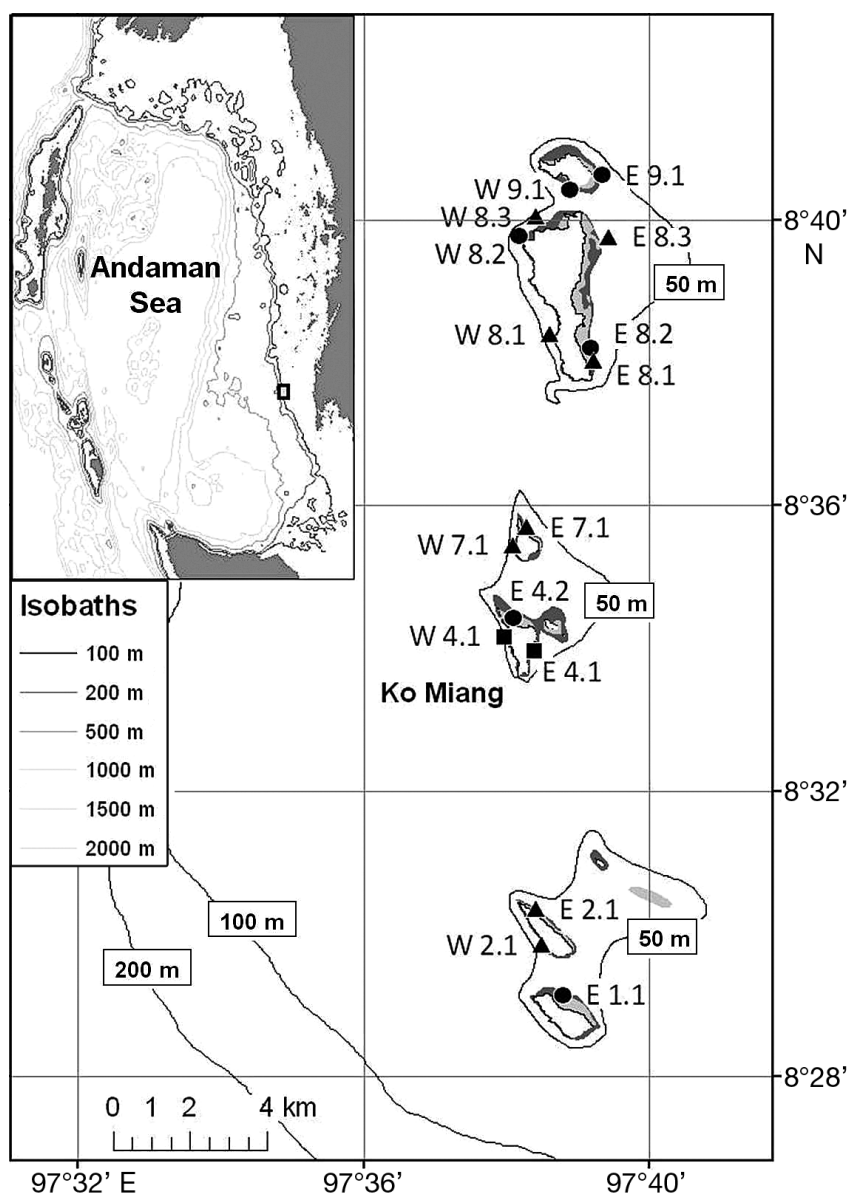

Fig. 2. Upper left panel: Andaman Sea basin with the Andaman-Nicobar Islands in the west and Thai coast in the east (land area marked grey, isobath scale). Main panel: close-up of the marked box in the upper left panel, with the Similan Islands (marked white) surrounded by shallow (down to $10 \mathrm{~m}$ depth, light grey) and deeper reef areas (down to $25 \mathrm{~m}$ depth, dark grey), with biological and environmental sampling sites: transects only (14 m depth) $(0)$; transects $(14 \mathrm{~m}$ depth) and temperature ( 7 and $20 \mathrm{~m}$ depth) $(\mathbf{\Delta})$; all parameters including transects at 7,14 and $20 \mathrm{~m}$ depth (ם) at the central island Ko Miang (W 4.1 and E 4.1) (figure modified after Jackson 2004) rocky islands composing the archipelago are aligned from north to south over a distance of about $24 \mathrm{~km}$, almost perfectly perpendicular to the direction of the LAIW (coming mainly from the west; Jackson 2004), and at an oblique angle $\left(45^{\circ}\right)$ to the SW monsoon (Fig. 2). Their topography and surrounding bathymetry are characterized by a generally steep slope $\left(>40^{\circ}\right)$ down to $20 \mathrm{~m}$ depth along the western sides and a slightly gentler slope $\left(<35^{\circ}\right)$ in the east, with broad sandy beaches and shallow reefs. The upper western slope features large boulders until about $15 \mathrm{~m}$ depth before giving away to rubble and coarse sand. The average depth around and between the islands is $70 \mathrm{~m}$ (Fig. 2). In the east, the upper slope is shallow (5 to $10 \mathrm{~m}$ ), with reefs and fine carbonate sands extending about $30 \mathrm{~m}$ from the island shores. The deeper slope is steep and covered with corals to a depth of about $30 \mathrm{~m}$. Annual rainfall is $3560 \mathrm{~mm}$ and mostly restricted to the SW monsoon between May and October.

\section{Benthic sampling}

For the coral community study, 16 localities were selected: 9 were distributed along the eastern sides of the Similan Islands (E 1.1 to E 9.1; Fig. 2) and sheltered from direct upwelling and monsoon impact; 7 were distributed along the western sides (W 2.1 to W 9.1; Fig. 2) and exposed to the full impact of deep waters and monsoon. Although precaution was taken to obtain a representative dataset, logistical constraints caused some sites to be more clustered (W 8.2. and W 8.3, E 8.1 and E 8.2) than preferable on theoretical grounds. To explore the west-east differences in the benthic composition, one $100 \mathrm{~m}$ line transect was established at $14 \mathrm{~m}$ depth at each of the 16 localities (marked in each case with W 14 m and E $14 \mathrm{~m}$, respectively) and marked with steel stakes, one at either end. The line-point-intercept method (LPI; Loya 1972) was adopted with measuring points every $50 \mathrm{~cm}\left(\mathrm{n}=200\right.$ data points transect $\left.{ }^{-1}\right)$. At each point the benthic component (i.e. scleractinian corals, soft corals, macroalgae, rock, sand and rubble) under the transect line was recorded, and the number of individuals was counted. Scleractinian corals were identified to species level. To establish vertical differences in the composition of the main macrobenthic groups at low taxonomic resolution (no species identification), additional triplicate transects of $50 \mathrm{~m}$ length were conducted at Ko Miang on both west (W 4.1) and east (E 4.1) sides at $20 \mathrm{~m}$ and $7 \mathrm{~m}$ depth (W $20 \mathrm{~m}$ and E $20 \mathrm{~m}, \mathrm{~W} 7 \mathrm{~m}$ and E $7 \mathrm{~m}$, 
respectively). These transect lines were positioned one after another along the respective isobath with a distance of $10 \mathrm{~m}$ between the end of one and the beginning of the next. Again, the LPI method was adopted as described above $(n=100$ data points transect $^{-1}$, analysis of similarity [ANOSIM] between tripicate transects to exclude auto-correlation; see Table S5 in the supplement at www.int-res.com/ articles/suppl/m456p113.pdf).

Carbonate framework development was assessed on both west and east sides of islands 4.1 and 8.1 (at 4.1 at 7 and $20 \mathrm{~m}$ depths and at 8.1 at $14 \mathrm{~m}$ depth) from scaled photographs, showing the elevation of the coral framework above its basement (sediment or rock) and a measuring stick positioned perpendicular to the isobaths in front of the framework. Images were taken every $5 \mathrm{~m}$ along the transects (where applicable, i.e. corals were present). The height of the framework was calculated by image analysis with the software ImageJ as the closest distance (in $\mathrm{cm}$ ) between the top 10 tips of corals and the basement. A total of 207 framework measurements was carried out $-21,67$ and 59 in the west at 7, 14, and $20 \mathrm{~m}$ depth, respectively, and 16, 28 and 16 each in the east at 7,14 and $20 \mathrm{~m}$ depth, respectively.

\section{Physico-chemical sampling}

Temperature measurements

A total of 20 temperature recorders (TidbiT v2, Onset computers; resolution $0.2^{\circ} \mathrm{C}$ within a range of 0 to $50^{\circ} \mathrm{C}$ ) recording temperature at $6 \mathrm{~min}$ intervals were deployed at 2 depths $(20$ and $7 \mathrm{~m}$ ) and exposures (west and east) at 5 study sites $(2.1,4.1,7.1,8.1$ and 8.3; Fig. 2). Loggers were attached about $20 \mathrm{~cm}$ above the substrate and kept for 21 mo from February 2007 to November 2008. Additional temperature loggers were deployed at the island Ko Miang (W 4.1 and $E$ 4.1) at 7, 14 and $20 \mathrm{~m}$ depths logging for $4 \mathrm{mo}$ from December 2007 through March 2008. Intercalibration of the TidbiT loggers after the long-term deployment showed small temperature differences between loggers $\left(\max .0 .8^{\circ} \mathrm{C}\right.$ ) contrasted by up to $10^{\circ} \mathrm{C}$ temperature variations in the course of the pulsed upwelling events.

\section{CTD and light measurements}

Temperature, salinity, pressure, oxygen, $\mathrm{pH}$, chlorophyll a fluorescence and optical backscatter were measured in 1 min intervals with a CTD (Seacat SBE 19plus, Sea-Bird Electronics) deployed at $20 \mathrm{~m}$ depth on the west side (W 4.1) of Ko Miang (Fig. 2) in March 2007 for $4 \mathrm{wk}$. Light loggers (Onset pendant light logger: 0 to $320000 \mathrm{lux}\left[\mathrm{lm} \mathrm{m}^{-2}\right]$ ) were deployed on both sides of Ko Miang (W 4.1, E 4.1) at 2 depths (20 and $7 \mathrm{~m}$ ) about $20 \mathrm{~cm}$ above the substrate recording light values every minute from December 2007 until April 2008. The loggers were cleaned daily to keep fouling organisms from interfering with light measurements. Additionally, a photosynthetic active radiation (PAR, umol quanta $\mathrm{m}^{-2} \mathrm{~s}^{-1}$ ) sensor (Biospherical Instruments) was mounted on a CTD (SEACAT, SBE 19plus, Sea-Bird Electronics) in January 2008 over a period of $20 \mathrm{~d}$ on the west side of Ko Miang (W 4.1) at $20 \mathrm{~m}$ depth.

\section{Chemical measurements}

A total of 89 water samples was collected by SCUBA during daily dives at Ko Miang in February and March of 2007 and 2008 (Fig. 2; at W 4.1: 21 samples at $20 \mathrm{~m}$, 18 samples at $7 \mathrm{~m}$ depth; at E 4.1: 25 samples each at 20 and $7 \mathrm{~m}$ depths). Samples were taken with $1 \mathrm{l}$ PE-bottles about $1 \mathrm{~m}$ above the reef substrate in the vicinity of the temperature loggers. The sampling time was recorded on each occasion for later correlation with water temperature. Immediately after collection, water samples were filtered through pre-combusted and pre-weighed glass-fibre filters (Whatman $\mathrm{GF} / \mathrm{F}, 45 \mu \mathrm{m}$ ) for determination of total suspended matter (TSM). The filters were kept frozen before drying at $50^{\circ} \mathrm{C}$ and determining dry weight of TSM gravimetrically (Mettler, AT21 Comparator, $1 \mu \mathrm{g}$ accuracy). Aliquots of the filtrate were stored in sterile polypropylene bottles after poisoning them with mercuric chloride (Kattner 1999) until inorganic nutrients (nitrate, nitrite, ammonium, phosphate and silicate) were analyzed according to Grasshoff et al. (1999) and Parsons et al. (1989) in a spectrophotometer (GBC Model UV/VIS981 with autosampler Model FS3000 in 2007, and Evolution III autoanalyzer, Alliance Instruments, in 2008). Further filtrate aliquots were transferred to pre-combusted glass ampoules spiked with phosphoric acid and flame sealed for determination of dissolved organic carbon (DOC). DOC samples were analyzed by means of high temperature catalytic oxidation using a Dohrman DC-190 Total Organic Carbon Analyzer equipped with a platinum catalyst. Before injection into the furnace, the acidified samples were decarbonated by purging with oxygen. The evolving $\mathrm{CO}_{2}$ 
was purified, dried and detected by a non-dispersive infrared detection system.

\section{Data processing and statistical analysis}

Biological and environmental data were tested for the assumption of normality and homogeneity of variances using Kolmogorov-Smirnov and Levene's tests, respectively, and subjected to parametric and non-parametric analyses, as required.

Transect data were processed as percentage abundances per site and analyzed with the software PRIMER v6 for non-parametric multivariate datasets (Clarke \& Gorley 2006). Analysis of similarities (ANOSIM) permutation tests based on Bray-Curtis similarities were used to detect spatial differences in substrate cover and species compositions between island sides (1-way analysis with 25 iteration steps). It was further used to clarify depth-dependent benthic cover and distribution of substrate types on the west and east sides of Ko Miang (2way-crossed design implicating the differing exposure depending on orientation: $\mathrm{W}$ versus $\mathrm{E}_{\text {; }}$ depth: 20 versus $7 \mathrm{~m}$ ). ANOSIM calculates a global R statistic that reflects the differences in variability between groups as compared to within groups (so $\mathrm{R}$ values are proportional to differences between the groups) and checks for the significance of R using permutation tests (Clarke \& Gorley 2006). Non-metric multidimensional scaling (NMDS) was used to further describe the benthic communities. Based on a similarity matrix, NMDS generates plots in which the distance between points is proportional to their degree of similarity (Clarke \& Gorley 2006). Similarity percentage (SIMPER) analyses were consulted to assess the respective contributions of substrate types and coral species to the similarities and dissimilarities within and among the west and east sites studied. Descriptive coral community factors such as the Shannon index, evenness and species richness (Rogers 1993) were calculated for every site and tested for exposure (west vs. east) using Student's $t$-tests. The effect of side (west and east) and depth $(7,14$ and $20 \mathrm{~m})$ on coral framework development was analyzed using ANOVA, with side and depth as treatment factors; post hoc, pairwise comparisons were performed via Tukey's HSD tests.

The calculation of degree days cooling $\left(\mathrm{DDC}_{i}{ }^{\circ} \mathrm{C} d\right)$ as a site-specific indicator of the upwelling involved the following steps: decomposing the temperature data into moving average and residuals, splitting the residuals into positive (warm) and negative (cold) values, and summing up the values for the cold residuals. Given the highly skewed distribution of the temperature data and the sensitivity of the arithmetic mean to outliers, it was appropriate to use the most common (or mode) temperature to represent the average. The moving average was calculated using a slide function (by Jos van der Geest; www. mathworks.com/matlabcentral/fileexchange/12550) with a $1 \mathrm{~d}$ time window for the mode value. The daily sum of cold residuals was divided by the number of samples per day. As not all loggers were recording without failure at all sites, the calculation of DDC was done for the period when data were available from all sites and depths (20 wk, February 2007 to July 2007, covering the SE and SW monsoon periods in roughly equal proportion). The relationship between physical (DDC), chemical (nutrients) and biological (coral community composition and cover) descriptors was assessed using linear-regression analyses.

Possible temperature differences (monthly minima, maxima and mode values) between sites corresponding to the same upwelling exposure (e.g. W $20 \mathrm{~m}$ ) were tested with Student's $t$-tests (Table S1 in the supplement at www.int-res.com/articles/suppl/m456 p113.pdf), and data for all sites that were not statistically different (at $p=0.01$ ) were pooled for further analyses. Temperature data, nutrient concentrations and light recordings were statistically tested for differences between west and east using nonparametric Kruskal-Wallis ANOVA by ranks. Linearregression analyses were undertaken to test the relationships between both chemical and physical parameters in the water as the dependent variables,

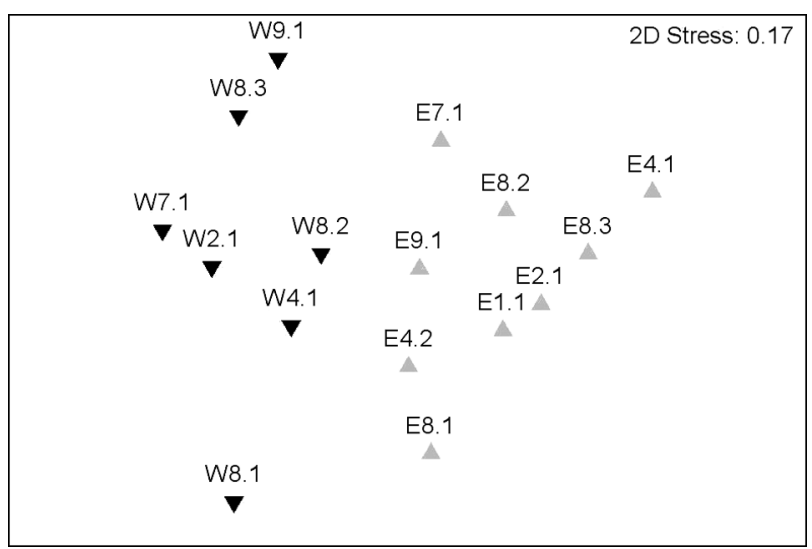

Fig. 3. NMDS ordination of coral communities at the Similan Islands based on species abundance data (\%) and BrayCurtis similarities from $1 \times 100 \mathrm{~m}$ transect at $14 \mathrm{~m}$ depth at each study site. West $(\boldsymbol{\nabla})$ and east $(\Delta)$ sites (see Fig. 2) grouped in separate clusters 
with temperature as the independent variable, followed by a Student's $t$-test to examine their statistical significance. If not stated otherwise data are always displayed as means $( \pm \mathrm{SE})$.

Table 1. Coral diversity indices (Shannon index $\left[H_{\mathrm{k}}\right]$, evenness $\left[E_{\mathrm{k}}\right]$, species richness $[S]$ ), and coral cover (as a fraction of hard substrate) determined from $1 \times 100 \mathrm{~m}$ transect at $14 \mathrm{~m}$ depth at each study site (all sites). At island Ko Miang (Sites W 4.1 and E 4.1, see Fig. 2) additional determination of coral cover at $20 \mathrm{~m}$ and $7 \mathrm{~m}$ depth from in each case $3 \times 50 \mathrm{~m}$ transects (mean $\pm \mathrm{SE}$ ). Linear regression model with $H_{\mathrm{k}}, E_{\mathrm{k}}$, $S$ and coral cover as dependent and degree days cooling $\left({ }^{\circ} \mathrm{C} \mathrm{d}\right)$ as independent variables $(\mathrm{n}=$ number of samples; significance levels are ${ }^{*} 0.05>p \geq 0.01,{ }^{* *} 0.01>p \geq 0.001$ )

\begin{tabular}{|c|c|c|c|c|c|c|}
\hline \multirow{2}{*}{$\begin{array}{l}\text { Depth } \\
\text { (m) }\end{array}$} & \multirow{2}{*}{ Index } & \multicolumn{2}{|c|}{ Site location } & \multirow{2}{*}{$\mathrm{n}$} & \multirow{2}{*}{$\mathrm{R}^{2}$} & \multirow[t]{2}{*}{$\mathrm{p}$} \\
\hline & & West & East & & & \\
\hline \multicolumn{7}{|c|}{ All sites } \\
\hline \multirow[t]{4}{*}{14} & $H_{\mathrm{k}}$ & 2.69 (0.15) & $2.03(0.13)$ & 10 & 0.4 & * \\
\hline & $E_{\mathrm{k}}$ & $0.74(0.04)$ & $0.63(0.04)$ & 10 & 0.07 & 0.46 \\
\hline & $S$ & $38.4(2.4)$ & $27.3(3.4)$ & 10 & 0.63 & $* *$ \\
\hline & Coral cover & $0.36(0.04)$ & $0.49(0.05)$ & 10 & 0.13 & 0.29 \\
\hline \multicolumn{7}{|c|}{ Ko Miang } \\
\hline $20 \quad C$ & Coral cover & $0.32(0.09)$ & $0.79(0.08)$ & 6 & 0.42 & 0.08 \\
\hline 14 & & 0.35 & 0.58 & & & \\
\hline 7 & & $0.54(0.04)$ & $0.54(0.03)$ & & & \\
\hline
\end{tabular}

\section{RESULTS}

\section{Reef data}

\section{Coral community composition}

A total of 144 hermatypic coral species was recorded, belonging to 40 genera and 17 families (Tables S2 \& S3 in the supplement). Coral species composition differed between island sides (ANOSIM, 1-way analysis: west versus east: global $\mathrm{R}=$ 0.585, p < 0.001, dissimilarity 83.2\%; Table S4) as seen also in the distinct clustering in the NMDS plot between west and east sites (Fig. 3). In the west, a higher species diversity ( $t$-test, $\mathrm{p}<0.01$ ), richness ( $t$-test, p < 0.02) and evenness ( $t$-test, p < 0.04; Table 1) was found compared to in the east. In the east all sites where characterized by a dominance of Porites species $(64.2 \%$ cover as a fraction of total coral cover compared to $15.7 \%$ in the west; Table S2 \& S3). The within-west and within-east similarities in species composition were low (24.3 and 31.9\%, respectively; Table S4), due to a variable number of rarer species mainly within the genera Acropora (28.6\% cover as a fraction of total coral cover in the west and $11.5 \%$ in the east) and Porites distributed

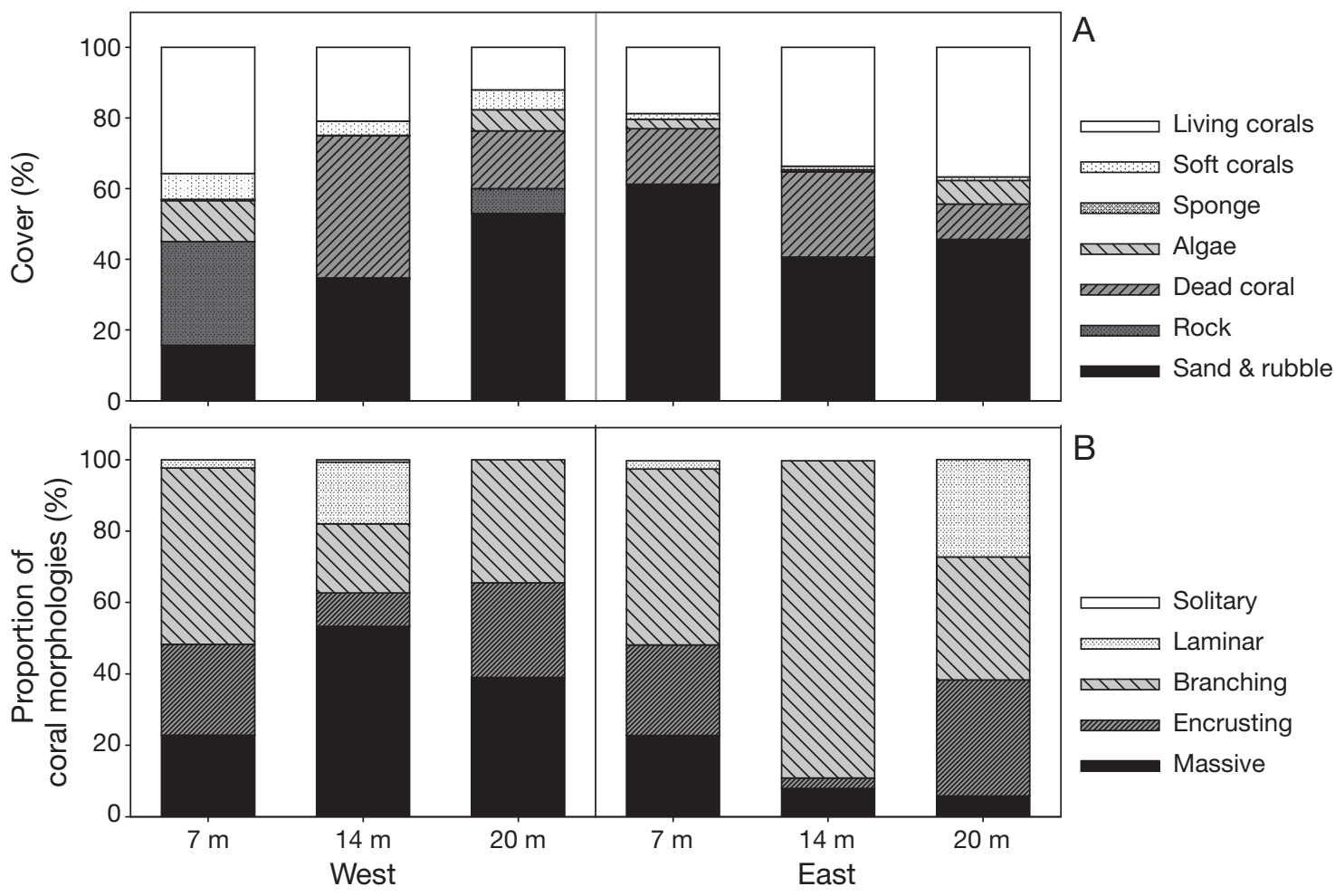

Fig. 4. Benthic composition at Ko Miang on exposed west (W 4.1) and sheltered east (E 4.1) sites (see Fig. 2), grouped by depth: 7, 14 and $20 \mathrm{~m}$ : (A) general benthic composition and (B) coral morphologies as fractions of total number of living colonies 
unevenly between the sites, particularly in the west (Tables S2 \& S3).

\section{Benthic substrate composition}

From the 2 sides (west, east) and 3 depths investigated at Ko Miang $(7,14$ and $20 \mathrm{~m}$ ), the lowest living coral cover was found at W 20 m (ANOSIM, 2-waycrossed analysis: W 4.1 versus E 4.1: global $\mathrm{R}=0.639$, $\mathrm{p}<0.02$; Fig. 4A). Significantly higher living coral cover was found at W $7 \mathrm{~m}(35.7 \pm 5.6 \%$ versus $12 \pm$ $4.4 \%$ at $20 \mathrm{~m}$ depth), E $20 \mathrm{~m}$ and E14 m (36.7 $\pm 4.6 \%$ at $20 \mathrm{~m}$ depth and $33.6 \%$ at $14 \mathrm{~m}$ depth versus $18.7 \pm$ $5.5 \%$ at $7 \mathrm{~m}$ depth; $20 \mathrm{~m}$ versus $7 \mathrm{~m}$ : global $\mathrm{R}=0.37$, $\mathrm{p}<0.05$; Fig. 4A). Living coral cover was the second most powerful contributor to the dissimilarity of $72.5 \%$ between west and east, with a contribution of $25.1 \%$; the most important contribution to this dissimilarity between west and east was achieved by sand and rubble with $35.9 \%$, followed by rock $(17.9 \%)$ in third position. At $14 \mathrm{~m}$ depth, differences in the benthic composition failed to be significant between west and east sides (ANOSIM, 1-way analysis: global $\mathrm{R}=0.079, \mathrm{p}=0.22$; Table $\mathrm{S} 5$ in the supplement at www.int-res.com/articles/suppl/m456p113 .pdf) due to similar distributions of total hard substrate consisting of dead coral, living coral and rock (with $67.7 \pm 6.6 \%$ in the west and $72.8 \pm 3.3 \%$ in the east), and sand including rubble (with $29.8 \pm 6.9 \%$ in the west and $25.9 \pm 3.3 \%$ in the east). Living coral cover exhibited higher differences between the west $(25.6 \pm 4.2 \%)$ and east $(35.9 \pm 4.6 \%)$ sides. Rock

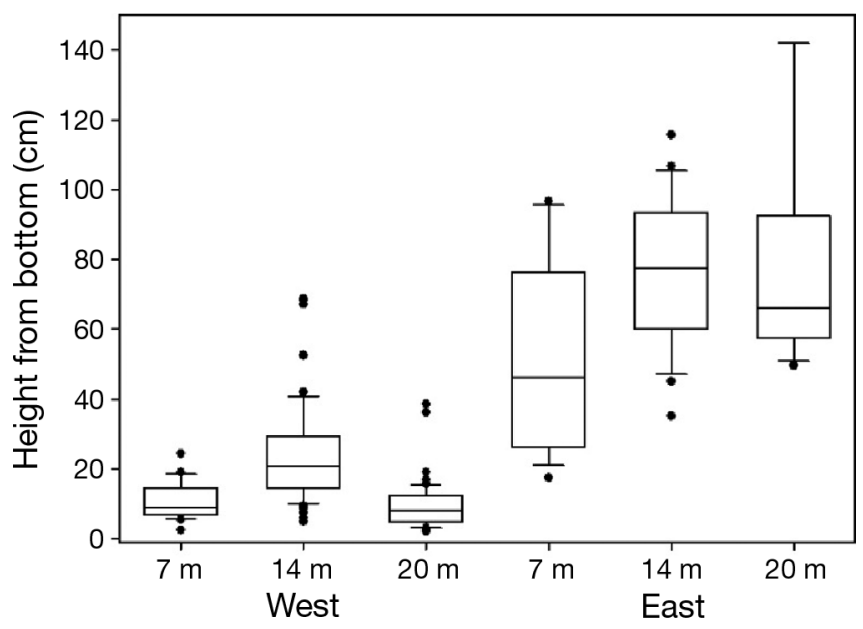

Fig. 5. Coral framework at the west and east sides of island Sites 4.1 ( 7 and $20 \mathrm{~m}$ ) and 8.1 (14 m) (see Fig. 2) grouped by depth: 7, 14 and $20 \mathrm{~m}$. Central tendency box plots show median with 25 th and 75 th percentiles and non-outlier range; extremes: dots structures were only found in the west, while in the east hard substrate consisted exclusively of dead coral (Fig. 4A, Table S6).

\section{Coral framework and morphologies}

A dense 3-dimensional coral framework characterized the east, whereas in the west hard corals were distributed as solitary colonies without developing an actual carbonate framework (ANOVA, Tukey HSDtests: $W$ versus E, $\mathrm{p}<0.001$; Fig. 5, Table S7). This was especially distinct at W $20 \mathrm{~m}$ and W $7 \mathrm{~m}$, whereas at W $14 \mathrm{~m}$ depth the framework was higher (ANOVA, Tukey HSD-test: $\mathrm{p}<0.001$; Fig. 5, Table S7). Coral morphologies differed significantly between sides (ANOSIM 2-way-crossed analysis: W versus E, global $\mathrm{R}=0.311, \mathrm{p}<0.05)$ and depths $(7$ versus $20 \mathrm{~m}$, side data pooled, global $\mathrm{R}=0.253$, $\mathrm{p}<0.05$ ) (Fig. 4B). The dominance of massive and encrusting colonies in the west and of branching species in the east of Ko Miang fell short of being significant $(t$-test, $p=0.064$ and $p=0.1$, respectively). Large massive and encrusting hard coral species sparely covered areas at W $20 \mathrm{~m}$, and small colonies of all morphological types grew very close to each other on the rocks in shallower west waters (Fig. 4B). Here, branching hard corals, especially within the genera Millepora and Acropora, often displayed flattened morphologies with pancake-like broadened bases and strongly reduced ramification (Fig. 1A).

\section{Physico-chemical environment}

The pattern of high- and low-variability periods and order of magnitude in amplitude in the temperature time series was consistent among all sites of the same depth and orientation (Fig. 6, cf. synchronous monthly mode, minimum and maximum temperature values, Student's t-tests: Table S1). This is also reflected by the differences between mean values and ranges (maximum to minimum temperature) of monthly temperature between west and east sites (Table 2; Kruskal-Wallis W $20 \mathrm{~m}$ versus E both depths: $p<0.00$; Table S8). Mode values differed only between W $20 \mathrm{~m}$ and E $7 \mathrm{~m}$ sites (Table 2; Kruskal-Wallis, $\mathrm{p}<0.01$; Table S8) and showed small $\left(<3.5^{\circ} \mathrm{C}\right)$ seasonal differences, irrespective of side or depth. The low seasonal variability contrasts with the high variability found at higher frequencies, as reflected by the large differences between mode and minima values showing declining temperature fluctuations: W $20 \mathrm{~m}>$ W $7 \mathrm{~m}>$ E $20 \mathrm{~m}>$ E $7 \mathrm{~m}$ (Fig. 6, 

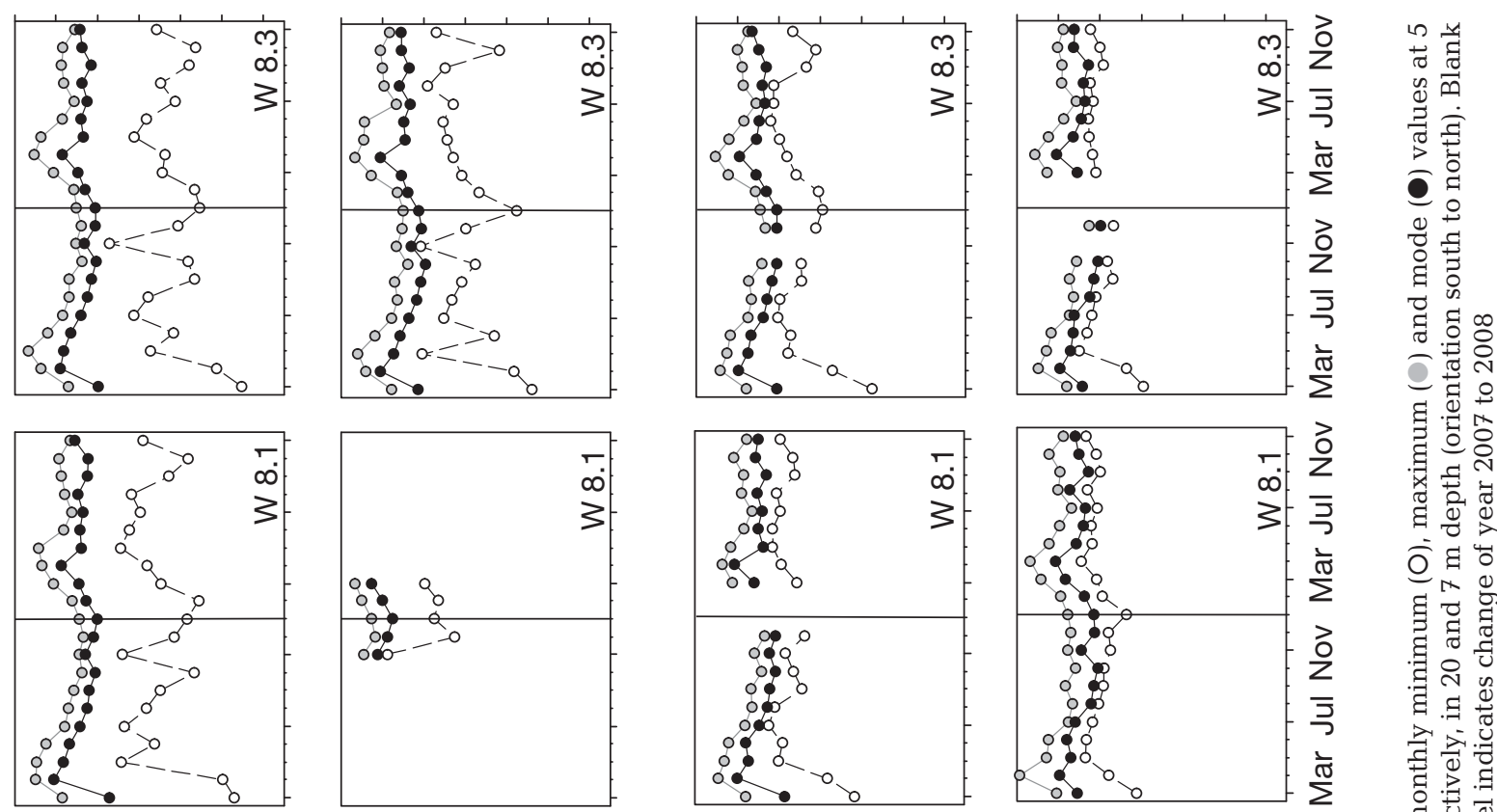

켤융
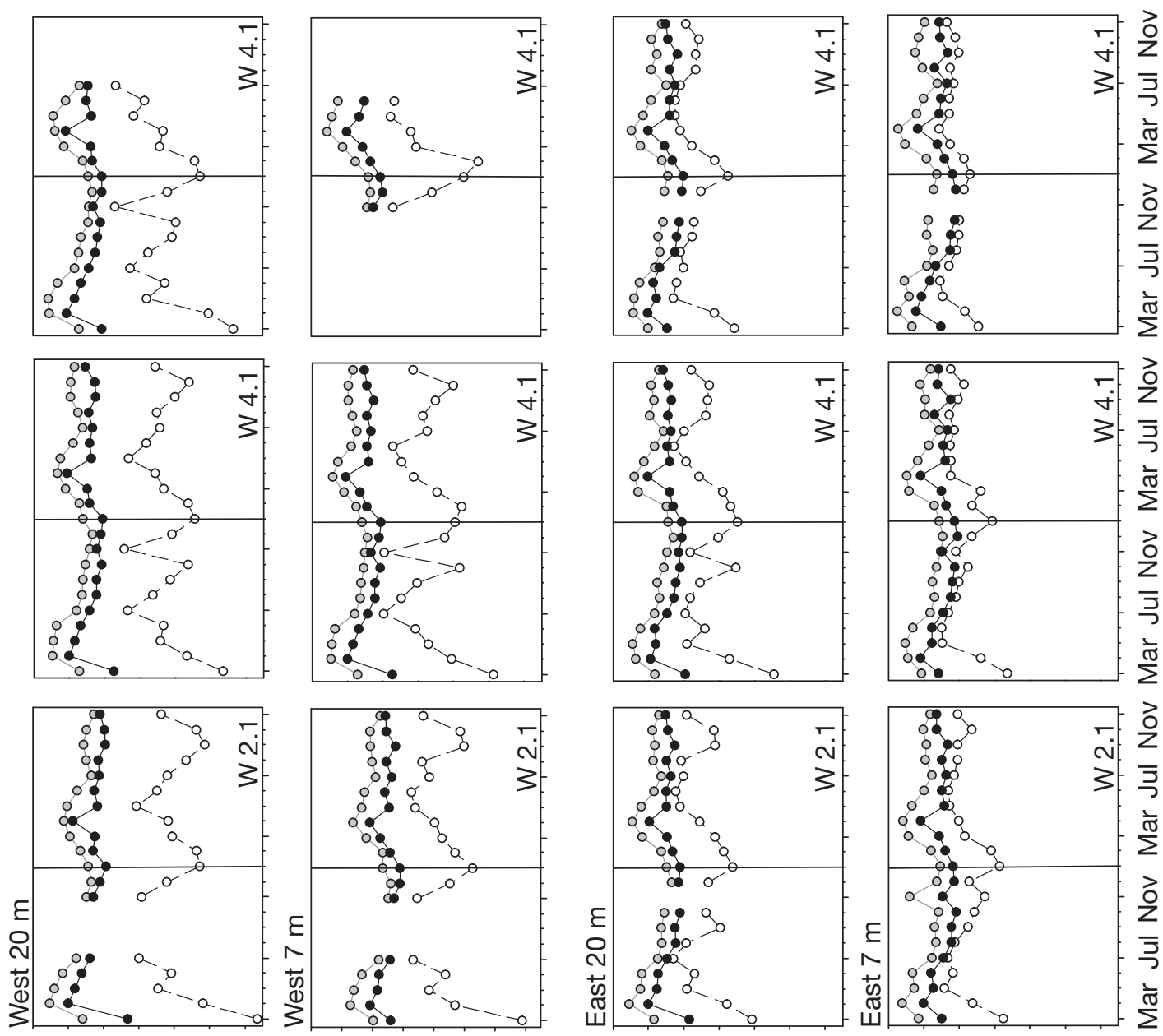

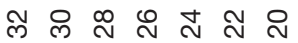

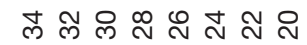

ల్లి Temperature $\left({ }^{\circ} \mathrm{C}\right)$

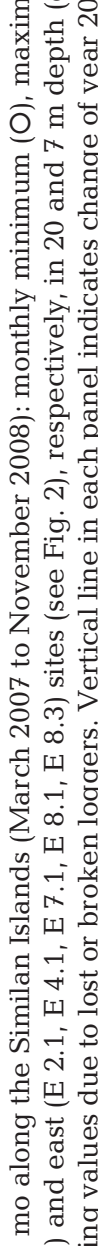

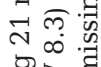

要造

$\begin{array}{lll}0 & 0 \\ 0 & 0 & 0 \\ 0 & 0 & 0 \\ 3 & 0 & 0 \\ 0 & -1 & 0\end{array}$

च

我

吾

牙 3 령 $\stackrel{1}{\circ}$ 它莴 
Table 2). Corresponding DDCs showed 5-fold higher values at W $20 \mathrm{~m}$ compared to E $7 \mathrm{~m}$ (Kruskal-Wallis test: $\mathrm{p}<0.001$; Table S8) and about 2- and 3-fold higher values than at $\mathrm{W} 7 \mathrm{~m}$ and $\mathrm{E} 20 \mathrm{~m}$, respectively (Table 2).

Fig. 7 shows a time series section of raw data at W $20 \mathrm{~m}$ at Ko Miang during strong temperature fluctuations. Synchronization of abrupt temperature decreases of up to $5-9^{\circ} \mathrm{C}$ occurred with drops in oxygen concentration of down to $12 \%$ (down to $21.8 \mu \mathrm{mol} \mathrm{l}^{-1}$ ), in $\mathrm{pH}$ of up to $0.6 \mathrm{U}$ (down to 7.75 ) and increases in salinity of up to 1.5 to values of 34.4. Sta-

Table 2. Summary of temperature data $\left({ }^{\circ} \mathrm{C}\right)$ : monthly mean, mode, range (maximum to minimum temperature), and degree days cooling (DDC, ${ }^{\circ} \mathrm{C} \mathrm{d}$, calculated for a $20 \mathrm{wk}$ period) $( \pm \mathrm{SD})$ for all sites recorded along the Similan Is-

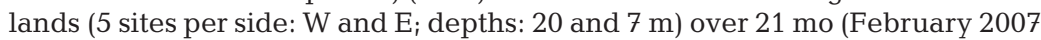
to November 2008) and for Ko Miang (west side: W 4.1, east side: E 4.1, depths 20, 14 and 7 m; see Fig. 2) over 5 mo (December 2007 through March 2008)

\begin{tabular}{|c|c|c|c|c|c|c|}
\hline & \multicolumn{3}{|c|}{ - West- } & \multicolumn{3}{|c|}{ - East } \\
\hline & $20 \mathrm{~m}$ & $14 \mathrm{~m}$ & $7 \mathrm{~m}$ & $20 \mathrm{~m}$ & $14 \mathrm{~m}$ & $7 \mathrm{~m}$ \\
\hline \multicolumn{7}{|c|}{ All sites } \\
\hline Mean & $28.5(0.7)$ & & $28.8(0.6)$ & $28.8(0.5)$ & & $29.1(0.5)$ \\
\hline Mode & $28.7(0.6)$ & & $28.9(0.1)$ & $28.8(0.6)$ & & $29.0(0.6)$ \\
\hline Range & $5.2(1.7)$ & & $4.3(1.7)$ & $2.7(1.3)$ & & $2.1(0.1)$ \\
\hline $\mathrm{DDC}$ & $-58.3(1.9)$ & & $-31.6(3.8)$ & $-24.6(2.5)$ & & $-11.8(4.9)$ \\
\hline \multicolumn{7}{|c|}{ Ko Miang } \\
\hline Mean & $28.0(0.8)$ & $28.3(0.7)$ & $28.6(0.5)$ & $28.4(0.5)$ & $28.4(0.4)$ & $28.6(0.5)$ \\
\hline Mode & $28.2(0.4)$ & $28.1(0.5)$ & $28.4(0.4)$ & $28.1(0.4)$ & $28.2(0.6)$ & $28.1(0.5)$ \\
\hline Range & $5.6(1.1)$ & $4.8(1.1)$ & $4.3(1.1)$ & $3.4(0.7)$ & $2.6(0.8)$ & $2.8(1.0)$ \\
\hline DDC & -70.6 & -39.0 & -16.3 & -23.0 & -9.3 & -9.3 \\
\hline
\end{tabular}

tistics did not support temperature-dependent variations in optical backscatter and chl a fluorescence (Fig. S1 in the supplement).

Highest light intensities (lux, $1 \mathrm{~m} \mathrm{~m}^{-2}$ ), were found at $\mathrm{E} 7 \mathrm{~m}$ and lowest at $\mathrm{W} 20 \mathrm{~m}$. Light conditions were significantly different in the west and east at both depths $(7$ and $20 \mathrm{~m})$ (Kruskal-Wallis test, $\mathrm{p}<0.001$; Table S9A), with over 3-fold higher light values in the east during midday and a longer lasting light environment at W $7 \mathrm{~m}$ at the end of the day (Fig. 8). This pattern can be explained by the topographical characteristics of all the islands, with high, steep slope-shaped west sides shading the west for longer than the east and flattened island topography in the east. During a period of high temperature variations in January 2007, PAR never exceeded $141.5 \mu \mathrm{mol}$ quanta $\mathrm{m}^{-2} \mathrm{~s}^{-1}$ at $\mathrm{W} 20 \mathrm{~m}$, with a mean of $102.5 \pm 3.4 \mu \mathrm{mol}$ quanta $\mathrm{m}^{-2} \mathrm{~s}^{-1}$.

Nutrient concentrations revealed significant differences between the west and east for nitrate and nitrite, as well as for silicate (Kruskal-Wallis test, $\mathrm{p}<0.001$ and $\mathrm{p}<0.04$, respectively). Mean concentrations of silicate were $>60 \%$ higher at W $20 \mathrm{~m}$ than at E $20 \mathrm{~m}$, supported by an increase of nitrate and nitrite $(40 \%)$ and of phosphate $(50 \%$ higher at W $20 \mathrm{~m}$ than at E $7 \mathrm{~m}$ ) concentrations (Table 3). In

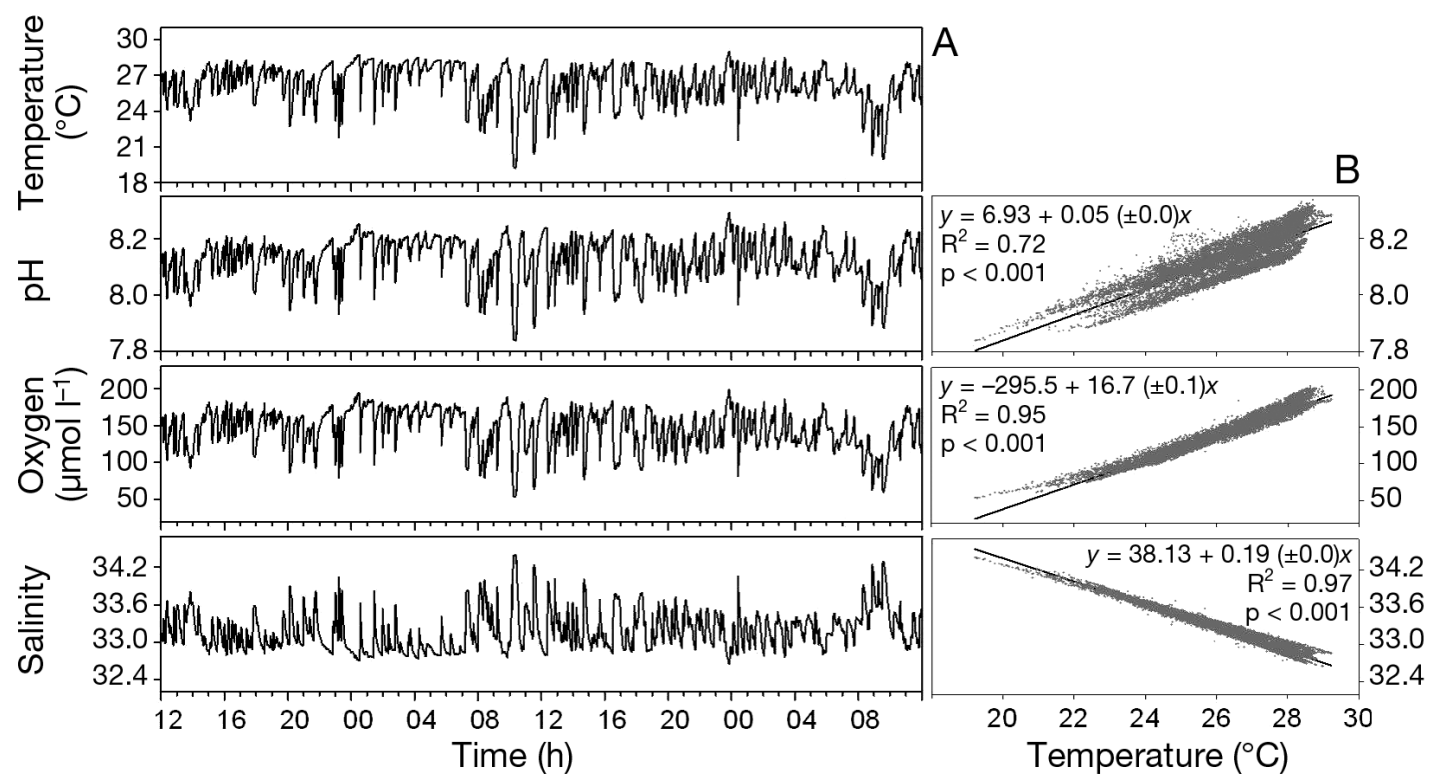

Fig. 7. (A) Raw data time series of a CTD recording from a $48 \mathrm{~h}$ section in March 2007 (temperature, pH, oxygen concentration, salinity) at Ko Miang west at $20 \mathrm{~m}$ depth (logging interval: $1 \mathrm{~min}$ ). (B) Linear-regression analysis, with pH, oxygen concentration and salinity as dependent variables, and temperature as the independent variable 


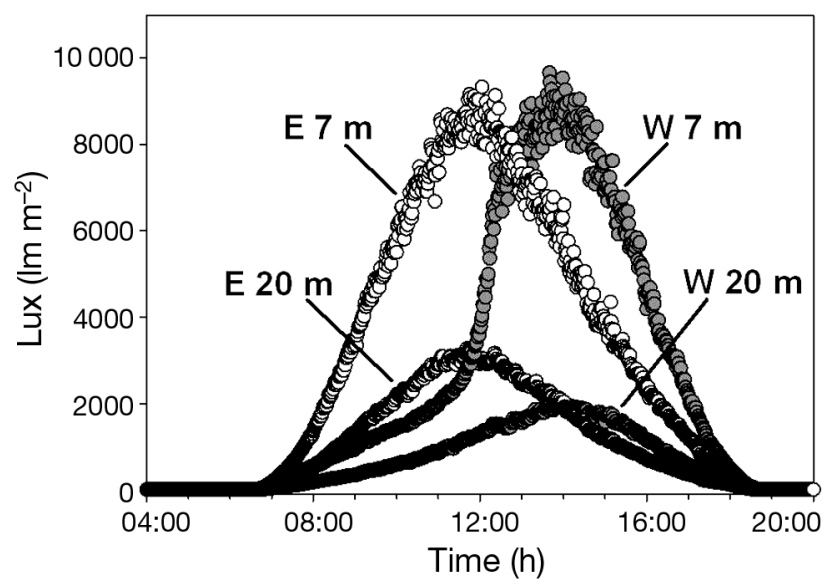

Fig. 8. Composite daily light curves at Ko Miang west (W 4.1) and east (E 4.1, see Fig. 2) at 20 and $7 \mathrm{~m}$ depths for a period of 30 d (February to March 2007; logging interval: $1 \mathrm{~min}$ )

Table 3. Environmental parameters determined from water samples at Ko Miang (W 4.1 and E 4.1) displayed as means $( \pm$ SE) and linear regression model with environmental parameters as dependent and water temperature (at time of sampling) as independent variables ( $\mathrm{n}=$ number of samples; significance level is $\left.{ }^{* * *} \mathrm{p}<0.001\right)$

\begin{tabular}{|c|c|c|c|c|c|c|}
\hline & \multirow[t]{2}{*}{ Units } & \multicolumn{2}{|c|}{ Depth } & \multicolumn{3}{|c|}{ Depths pooled } \\
\hline & & $20 \mathrm{~m}$ & $7 \mathrm{~m}$ & $\mathrm{n}$ & $\mathrm{R}^{2}$ & $\mathrm{p}$ \\
\hline \multicolumn{7}{|l|}{ West, W 4.1} \\
\hline Silicate & $\mu \mathrm{mol} \mathrm{l} \mathrm{l}^{-1}$ & $6.86(1.29)$ & $3.84(0.67)$ & 36 & 0.72 & $* * *$ \\
\hline Phosphate & $\mu \mathrm{mol} \mathrm{l} \mathrm{l}^{-1}$ & $0.42(0.08)$ & $0.21(0.03)$ & 35 & 0.41 & $* * *$ \\
\hline Nitrate + nitrite & $\mu \mathrm{mol} \mathrm{l} \mathrm{l}^{-1}$ & $2.11(0.47)$ & $0.74(0.15)$ & 36 & 0.65 & $* * *$ \\
\hline Ammonium & $\mu \mathrm{mol} \mathrm{l} \mathrm{l}^{-1}$ & $1.14(0.22)$ & $0.92(0.13)$ & 30 & 0.01 & 0.66 \\
\hline $\begin{array}{l}\text { Dissolved } \\
\text { organic carbon }\end{array}$ & ppm & $1.11(0.12)$ & $1.02(0.07)$ & 34 & 0.03 & 0.36 \\
\hline $\begin{array}{l}\text { Suspended } \\
\text { particulate matter }\end{array}$ & $\mathrm{mg} \mathrm{l}^{-1}$ & $12.40(0.68)$ & $13.75(1.03)$ & 37 & 0.09 & 0.07 \\
\hline \multicolumn{7}{|l|}{ East, E 4.1} \\
\hline Silicate & $\mu \mathrm{mol} \mathrm{l} \mathrm{l}^{-1}$ & $4.33(0.39)$ & $3.06(0.30)$ & 48 & 0.50 & $* * *$ \\
\hline Phosphate & $\mu \mathrm{mol} \mathrm{l} \mathrm{l}^{-1}$ & $0.30(0.05)$ & $0.23(0.03)$ & 42 & 0.03 & 0.18 \\
\hline Nitrate + nitrite & $\mu \mathrm{mol} \mathrm{l} \mathrm{l}^{-1}$ & $0.90(0.16)$ & $0.56(0.17)$ & 47 & 0.38 & $* * *$ \\
\hline Ammonium & $\mu \mathrm{mol} \mathrm{l} \mathrm{l}^{-1}$ & $0.98(0.12)$ & $0.92(0.09)$ & 35 & 0.21 & 0.06 \\
\hline $\begin{array}{l}\text { Dissolved } \\
\text { organic carbon }\end{array}$ & ppm & $1.58(0.31)$ & $1.03(0.07)$ & 43 & 0.01 & 0.56 \\
\hline $\begin{array}{l}\text { Suspended } \\
\text { particulate matter }\end{array}$ & $\mathrm{mg} \mathrm{l}^{-1}$ & $13.80(0.78)$ & $12.88(0.72)$ & 44 & 0.12 & 0.06 \\
\hline
\end{tabular}

shallow waters the differences may be still noticeable but are far less pronounced and statistically not significant. Nutrient concentrations exhibited a negative relationship with temperature when correlated to the in situ temperature during sampling (Table 3). No significant differences were found between the different sides of the island in ammonium concentration, dissolved organic carbon or suspended particulate matter which varied independently of temperature variations (Table 3, Table S9B in the supplement).

\section{Link between coral community parameters and DDC}

Diversity (Shannon index) and species richness determined at the intermediate depth of $14 \mathrm{~m}$ in the west and east exhibited a positive relationship with DDC (Table 1). Living coral cover as a fraction of the available hard substrate determined at 7,14 and $20 \mathrm{~m}$ depths in the west and east may be inversely related to DDC, but this correlation failed to be significant (Table 1).

\section{DISCUSSION}

The Similan Islands reveal a lack of coral reef framework development along their western sides, in contrast to the complex 3-dimensional coral framework in the east. The development of coral reefs in general has been reported to be undermined by cold water influence (Burns 1985, Kleypas et al. 1999). Although several tropical corals are known to occur over a wide geographical range of temperatures (e.g. up to $12^{\circ} \mathrm{C}$ differences in maximum summer temperatures for species co-occurring in the Arabian Sea and Lord Howe Island, Australia; Hughes et al. 2003), and can tolerate large annual ranges of temperature (up to $25^{\circ} \mathrm{C}$ ) and survive severe cold periods $\left(13^{\circ} \mathrm{C}\right.$ for several days; Coles \& Fadlallah 1991), cold water stress $\left(6\right.$ to $10^{\circ} \mathrm{C}$ under normal conditions) may disrupt the sensitive association between corals and their endosymbiotic zooxanthellae and result in a decreased fitness and growth performance of the coral host (Coles \& Fadlallah 1991, Gates et al. 1992, Saxby et al. 2003). The reduced coral cover in the west at $20 \mathrm{~m}$ depth and the absence of reef framework in the west may therefore be partly due to the observed temperature fluctuations. The cold temperatures in the present study, however, were only one stressor out of several cooccurring environmental factors. Temperature was negatively correlated with nutrient input (Table 3) and salinity, and positively with $\mathrm{pH}$ and oxygen concentration (Fig. 7). Thus, the cold water masses reaching the west of the Similan Islands may be derived from sub-pycnocline sources containing re- 
mineralized nutrients (Jackson \& Williams 1985) due to respiration and decomposition processes in areas isolated from additional oxygen supply (Levin et al. 1991). The covariance of temperature with these environmental parameters (Fig. 7, Table 3) allowed an assessment of the physico-chemical environment from temperature alone for periods where no other data were available. Exceptions were the dissolved organic matter and suspended particulate matter concentrations (see also optical backscatter; Fig. S1), which were independent of temperature and similar between west and east. Reduced oxygen and high nutrient concentrations in the sub-thermocline waters transported into shallow areas may possibly have led to a mutual compensation of depletion (low oxygen) and production processes (plankton production due to higher nutrient concentrations; Eppley et al. 1979) in the west. This could have been a reason for the lack of difference in dissolved organic matter concentrations between west and east. The similar particulate matter concentrations appeared inconsistent with the differences in the physical oceanographic variables and the varying light conditions between west and east sides. This could be explained by higher suspended particulate loads in the west than in the east caused by higher currents (Roder et al. 2011) and due to more intense resuspension. Mean nutrient concentrations for nitrate, nitrite and phosphate in the west were above the average concentrations of most tropical reefs (Table 3, Kleypas et al. 1999). During periods of high temperature fluctuations (February, March) they were close to or even above the extreme values assessed for coral reef communities (Kleypas et al. 1999). Increased nutrient concentrations entail neutral or positive effects on coral nutrition, physiology and zooxanthellae concentrations (Muscatine et al. 1989, Ferrier-Pagès et al. 2001). The combination of higher current velocities and nutrient concentrations can enhance coral nutrient uptake (Hearn et al. 2001) and photosynthesis (Szmant 2002). Accordingly, higher pigment concentrations in western corals were indicative of their similar net photosynthetic rates compared to sheltered eastern corals (Jantzen 2010). Several coral species of different morphology and growth rates along the Similan Islands displayed higher pigment concentrations, protein content and biomass under the influence of increased nutrient concentrations and higher planktonic food supply in the west (Roder et al. 2010, 2011). However, these positive effects on coral nutrition and photosynthetic performance may be small compared to the negative direct effects of nutrients and low $\mathrm{pH}$ on coral calcification and growth (Kinsey
\& Davies 1979, Ferrier-Pagès et al. 2000). Values of $\mathrm{pH}$ decreased during cold-water intrusions in the west (up to $0.6 \mathrm{U}$; Fig. 7). This effect in combination with reduced light intensities (Fig. 8) may be the main reason for the significantly reduced coral growth at W $20 \mathrm{~m}$ depth (Schmidt et al. unpubl. data), as both processes are tightly coupled in zooxanthellate corals and their efficiency suffers from lowered $\mathrm{pH}$ and light levels (Marubini et al. 2001). This might also be a major reason for the inability of the corals in the west to develop a reef framework (Manzello et al. 2008).

The pulsed extreme conditions in the chemical and physical environment are replaced each time within 15 to 30 min, again by warm surface water (see Fig. 7; nearly identical mode temperature values in the west and east; Table 2). The intensity of these fluctuations increases with depth $(7 \mathrm{~m}<14 \mathrm{~m}<20 \mathrm{~m})$, but does not seem to cause severe physiological damage or mortality as observed for long-term disturbances following cold spells (Coles \& Fadlallah 1991) or eutrophication (Szmant 2002). Monsoonal storms, on the other hand, occur at monthly or seasonal frequencies (Wu \& Zhang 1998) and last for days. Their impact diminishes with depth. When looking at the intermediate depth of $14 \mathrm{~m}$ in the west, the coral framework was higher than in deep $(20 \mathrm{~m})$ and shallow $(7 \mathrm{~m})$ waters, and high coral diversity was found in contrast to the sheltered eastern reefs (Table 1). In the east species diversity may be lower in the absence of disturbance due to competitive exclusion in an equilibrated system (Connell 1978), with high coral cover but less species dominating the communities and no available free substrate for new settlers (no bare rock in the east; Table S6). In the west, however, the seasonal alternation of temperature fluctuations (January through April) and monsoonal surface waves (May through October) may be a disturbance which represents a selective regime (Karlson 1980) to which organisms adapt and generate a variety of competitive mechanisms (Karlson \& Hurd 1993). This non-equilibrium state may reset succession, with regularly new settling corals on the available free substrate (bare rock in the west; Table S6), and thus enhance coral development and coral species diversity (Connell 1997).

Going deeper to $20 \mathrm{~m}$ depth along the western Similan Islands, the reef assemblage is impoverished, with single corals growing apart from each other (Figs. 4B \& 5). This is reminiscent of coral communities described for upwelling-influenced sites dominated by only one or a few species, such as mainly Porites, Acropora. and Pocillopora. (Benzoni et al. 2003). Slow-growing, massive and sub-massive species dominated the community here (Fig. 4, Tables S2 
\& 3). Corals of this type are often described as stresstolerators (Riegl \& Piller 2000, Veron 2000, Benzoni et al. 2003), with high adaptive tolerance to different types of environmental stress (Marshall \& Baird 2000, Alutoin et al. 2001, Fabrizius et al. 2011). This was also shown by Roder et al. (2011) who found high metabolic plasticity in the species Porites lutea and Diploastrea heliopora to the fluctuating chemical conditions in the west of the Similan Islands. The general abundance of branching species was reduced in the west compared to in the east (Fig. 4B); however, Acropora species showed comparatively higher abundances in the west. Possibly Acropora corals were able to benefit more than other coral species from the changes in environmental conditions between upwelling and monsoon-impact periods. Most of them are fast-growing species (Veron 2000) and able to recover rapidly from disturbances and spread by using broken coral fragments as new settling colonies (Highsmith 1982). Light-catching table-like morphotypes of branching colonies which would have been due to the reduced light conditions with increasing depth (Macintyre \& Smith 1974) were rare in the west. This indicates that hydrodynamics in the west, due to the high current speeds correlated with cold water (Roder et al. 2010) and due to surface gravity waves, may have reduced the number of sheltered sites for these exposed growth forms. Especially the shallow $(7 \mathrm{~m})$, western corals showed growth patterns as described for high-wave-energy areas (Storlazzi et al. 2001, 2003) nestled and disjointed directly to the granite basement with robust or fast-growing colonizing species. However, the impact of surface gravity waves can only be estimated as we lack knowledge of their actual intensity and maximum depth range for our study area. We suppose that, in contrast to most other reef sites, coral morphologies, species distribution and reef development in the west are affected by both hydrodynamics in shallow areas causing coral breakage and leading to hampered 3-dimensional reef development (Fig. 5, Grigg 1998) and the highly fluctuating physico-chemical conditions with increasing depth.

In summary, the composition of a coral community reflects the interaction of the governing physical, chemical and biological drivers (De Vantier et al. 1998). The coral communities growing along the western Similan Islands are exposed to a stressful physico-chemical environment. They appear to be adapted to mechanical disturbances, such as strong surface waves, and they deal successfully with the pulsed frequent supply of sub-pycnocline waters into their low-light environment. They appear to exist in species-rich communities where regular disturbance produces a highly successional community structure.

\section{Caveats to the conclusions}

The western Similan Islands were found to be exposed to temperature fluctuations (see also Roder et al. 2010, 2011) which are more frequent and severe than reported earlier elsewhere (Leichter et al. 1996, 2003), and rank among the largest ones so far reported in tropical shallow reef areas above $30 \mathrm{~m}$ depth (Wolanski et al. 2004, Sheppard 2009). Seasonal variations, revealing the strongest temperature fluctuations during the late NE monsoon (March; Fig. 6) may be related to variations in the depth and strength of the pycnocline: the shallow pycnocline during the NE monsoon corresponds to the strongest LAIW activity (Nielsen et al. 2004). The pulsed, short-term fluctuations of temperature to the order of minutes, periodic occurrences in several events per day (Fig. 7) and seasonal variations (Fig. 6; see also Wolanski et al. 2004 and Storlazzi et al. 2003) indicate that they may be caused by LAIW reaching these shallow-water areas. The especially high temperature variability in 2007 compared to 2008 (Fig. 6) may be related to the untypical positive Indian Ocean Dipole event in 2007 (Behera et al. 2008) with stronger upwelling events (Webster et al. 1999) and likely internal waves.

Even though LAIW seem to be the likely source of the observed temperature fluctuations, other possible factors, such as current-driven advection of cold waters (Andrews \& Gentien 1982) or seasonal winddriven upwelling (D'Croz \& O'Dea 2007), cannot be excluded. Research in this area has just started and needs to be expanded further to include data not only on the NE monsoon period but also the SW monsoon, to complement our knowledge on surface wave impacts and to disentangle the differential influences of upwelling and surface waves on coral reef development. In addition, verification of the primary drivers of the temperature fluctuations - these may be currents, tides or internal waves - would complement the present approach and set it in its oceanographic context.

Acknowledgements. The research for the present study was funded by the German Research Foundation (DFG, RI 1074/7-1), the National Research Council of Thailand (NRCT), and the German Federal Ministry for Education and Research (BMBF, Grant Number: 03F0608B, Bioacid 3.2.3, Coral calcification in marginal reefs). The authors thank the Phuket Marine Biological Center (PMBC) and the Similan Islands National Park staff for field assistance, as well as Tobias Funke for technical, and Matthias Birkicht and Dorothee Dasbach for laboratory assistance. 


\section{LITERATURE CITED}

Allen GR, Stone GS (2005) Rapid assessment survey of Tsunami-affected reefs of Thailand. Technical Report 0205, New England Aquarium, Boston, MA

Alutoin S, Boberg J, Nyström M, Tedengren M (2001) Effects of the multiple stressors copper and reduced salinity on the metabolism of the hermatypic coral Porites lutea. Mar Environ Res 52:289-299

> Andrews JC, Gentien P (1982) Upwelling as a source of nutrients for the Great Barrier Reef ecosystem: A solution to Darwin's question? Mar Ecol Prog Ser 8:257-269

> Behera SK, Luo JJ, Yamagata T (2008) Unusual IOD event in 2007. Geophys Res Lett 35:L14S11 doi: 10.1029/2008GL 034122

Benzoni F, Bianchi CN, Morri C (2003) Coral communities of the northwestern Gulf of Aden (Yemen): variation in framework building related to environmental factors and biotic conditions. Coral Reefs 22:475-484

$>$ Brown BE (1997) Adaptations of reef corals to physical environmental stress. Adv Mar Biol 31:221-299

Burns TP (1985) Hard-coral distribution and cold-water disturbances in South Florida: variation with depth and location. Coral Reefs 4:117-124

Chazottes V, Le Campion-Alsumard T, Peyrot-Clausade M, Cuet $P$ (2002) The effects of eutrophication-related alterations to coral reef communities on agents and rates of bioerosion (Reunion Island, Indian Ocean). Coral Reefs 21:375-390

Clarke KR, Gorley RN (2006) PRIMER v6: user manual/tutorial. PRIMER-E, Plymouth

Coles SL, Fadlallah YH (1991) Reef coral survival and mortality at low temperatures in the Arabian Gulf: new species-specific lower temperature limits. Coral Reefs 9: 231-237

> Connell JH (1978) Diversity in tropical rain forests and coral reefs. Science 199:1302-1310

> Connell JH (1997) Disturbance and recovery of coral assemblages. Coral Reefs 16(Suppl):101-113

> D'Croz LD, O'Dea A (2007) Variability in upwelling along the Pacific shelf of Panama and implications for the distribution of nutrients and chlorophyll. Estuar Coast Shelf Sci 73:325-340

De Vantier LM, Death G, Done TJ, Turak E (1998) Ecological assessment of a complex natural system: a case study from the Great Barrier Reef. Ecol Appl 8:480-496

Eppley RW, Renger EH, Harrison WG (1979) Nitrate and phytoplankton production in southern California coastal waters. Limnol Oceanogr 24:483-494

Fabrizius EF, Langdon C, Uthicke S, Humphrey C and others (2011) Losers and winners in coral reefs acclimatized to elevated carbon dioxide concentrations. Nat Clim Chang 1:165-169

Ferrier-Pagès C, Gattuso JP, Dallot S, Jaubert J (2000) Effect of nutrient enrichment on growth and photosynthesis of the zooxanthellate coral Stylophora pistillata. Coral Reefs 19:103-113

Ferrier-Pagès C, Schoelzke V, Jaubert J, Muscatine L, Hoegh-Guldberg O (2001) Response of a scleractinian coral, Stylophora pistillata, to iron and nitrate enrichment. J Exp Mar Biol Ecol 259:249-261

Gates RD, Baghdasarian G, Muscatine L (1992) Temperature stress causes host cell detachment in symbiotic cnidarians: implications for coral bleaching. Biol Bull 182:324-332
Grasshoff K, Ehrhardt M, Kremling K (1999) Methods of seawater analysis, 3nd edn. Verlag Chemie, Weinheim

Grigg RW (1998) Holocene coral reef accretion in Hawaii: a function of wave exposure and sea level history. Coral Reefs 17:263-272

Hallock P, Schlager W (1986) Nutrient excess and the demise of coral reefs and carbonate platforms. Palaios 1:389-398

- Hearn C, Atkinson M, Falter J (2001) A physical derivation of nutrient-uptake rates in coral reefs: effects of roughness and waves. Coral Reefs 20:347-356

Highsmith RC (1982) Reproduction by fragmentation in corals. Mar Ecol Prog Ser 7:207-226

Hughes TP, Baird AH, Bellwood DR, Card M and others (2003) Climate change, human impacts, and the resilience of coral reefs. Science 301:929-933

Jackson CR (2004) An atlas of internal solitary-like waves and their properties, 2nd edn. Office of Naval Research, Global Ocean Associates, Alexandria, VA

> Jackson GA, Williams GM (1985) Importance of dissolved organic nitrogen and phosphorus to biological nutrient cycling. Deep-Sea Res 32:223-235

Jantzen C (2010) Primary production in coral reefs, key players and adaptive strategies to natural environmental variations. PhD thesis, University of Bremen

Karlson RH (1980) Alternative competitive strategies in a periodically disturbed habitat. Bull Mar Sci 30:894-900

> Karlson RH, Hurd LE (1993) Disturbance, coral reef communities, and changing ecological paradigms. Coral Reefs $12: 117-125$

Kattner G (1999) Storage of dissolved inorganic nutrients in seawater: poisoning with mercuric chloride. Mar Chem 67:61-66

Kinsey DW, Davies PJ (1979) Effects of elevated nitrogen and phosphorus on coral reef growth. Limnol Oceanogr 24:935-940

Kleypas JA, McManus JW, Lambert Meñez AB (1999) Environmental limits to coral reef development: Where do we draw the line? Am Zool 39:146-159

Leichter JJ, Wing SR, Miller SL, Denny MW (1996) Pulsed delivery of subthermoline water to Conch Reef (Florida Keys) by internal bores. Limnol Oceanogr 41:1490-1501

Leichter JJ, Stewart HL, Miller SL (2003) Episodic nutrient transport to Florida coral reefs. Limnol Oceanogr 48: 1394-1407

Levin LA, Huggett CL, Wishner KF (1991) Control of deepsea benthic community structure by oxygen and organicmatter gradients in the eastern Pacific Ocean. J Mar Res 49:763-800

Levitus S, O'Brien TD (1998) World ocean atlas, Vol 34, XI. National Environmental Satellite, Data, and Information Service, NOAA atlas NESDIS, United States, Silver Spring, WA

> Loya Y (1972) Community structure and species diversity of hermatypic corals at Eilat, Red Sea. Mar Biol 13:100-123

Macintyre IG, Smith SV (1974) X-radiographic studies of skeletal development in coral colonies. In: Proc 2 nd Int Coral Reef Symp, Brisbane 2:227-287

Manzello DP, Kleypas JA, Budd DA, Eakin CM, Glynn PW, Langdon C (2008) Poorly cemented coral reefs of the eastern tropical Pacific: possible insights into reef development in a high- $\mathrm{CO}_{2}$ world. Proc Natl Acad Sci USA 105:10450-10455

Marshall PA, Baird AH (2000) Bleaching of corals on the Great Barrier Reef: differential susceptibilities among taxa. Coral Reefs 19:155-163 
Marubini F, Barnett H, Langdon C, Atkinson MJ (2001) Dependence of calcification on light and carbonate ion concentration for the hermatypic coral Porites compressa. Mar Ecol Prog Ser 220:153-162

McCook LJ, Jompa J, Diaz-Pulido G (2001) Competition between corals and algae on coral reefs: a review of evidence and mechanisms. Coral Reefs 19:400-417

Muscatine L, Falkowski PG, Dubinsky Z, Cook PA, McCloskey LR (1989) The effect of external nutrient resources on the population dynamics of zooxanthellae in a reef coral. Proc R Soc Lond B Biol Sci 236:311-324

Nielsen TG, Bjørnsen PK, Boonruang P, Fryd M and others (2004) Hydrography, bacteria and protist communities across the continental shelf and shelf slope of the Andaman Sea (NE Indian Ocean). Mar Ecol Prog Ser 274:69-86

Osborne AR, Burch TL (1980) Internal solitons in the Andaman Sea. Science 208:451-460

Parsons TR, Maita Y, Palli CM (1989) A manual of chemical and biological methods for seawater analysis. Pergamon Press, New York, NY

Phongsuwan N, Yamarunpattana C, Paokanta Y, Areechon $P$ (2008) Status of coral reefs in the Surin and Similan Archipelagos, Thailand. In: Obura DO, Tamelander J, Linden $\mathrm{O}$ (eds) Ten years after bleaching-facing the consequences of climate change in the Indian Ocean. CORDIO Status report 2008, Mombasa

Pineda J (1991) Predictable upwelling and the shoreward transport of planktonic larvae by internal tidal bores. Science 253:548-559

Plathong S (2005) Survey of tsunami impact on coral reef and the reef recovery project for Similan Islands Marine National Park. Coral Reef and Benthos Res Unit, Centre Biod Penins Thailand, Dep Biol, Prince of Songkla University Had Yai, Songkla

Riegl B, Piller WE (2000) Upwelling areas as possible refugia for reefs in times of rising SST? Further evidence from the Caribbean and Indian Oceans. In: Proc 9th Int Coral Reef Symp, Vol 1. International Coral Reef Society, Bali, p 315-320

Roder C, Fillinger L, Jantzen C, Schmidt GM, Khokiatti-

Editorial responsibility: Charles Birkeland,

Honolulu, Hawaii, USA wong S, Richter C (2010) Trophic response of corals to large amplitude internal waves. Mar Ecol Prog Ser 412: 113-128

> Roder C, Jantzen C, Schmidt GM, Kattner G, Phongsuwan N, Richter C (2011) Metabolic plasticity of the corals Porites lutea and Diploastrea heliopora exposed to large amplitude internal waves. Coral Reefs 30:57-69

Rogers CS (1993) Hurricanes and coral reefs: the intermediate hypothesis revisited. Coral Reefs 12:127-137

$>$ Saxby T, Dennison WC, Hoegh-Guldberg O (2003) Photosynthetic response of the coral Montipora digitata to cold temperature stress. Mar Ecol Prog Ser 248:85-97

Sheppard C (2009) Large temperature plunges recorded by data loggers at different depths on an Indian Ocean atoll: comparison with satellite data and relevance to coral refuges. Coral Reefs 28:399-403

Storlazzi CD, Field ME, Dykes JD, Jokiel PL, Brown E (2001) Wave control on reef morphology and coral distribution: Molokai, Hawaii. http://137.227.239.66/reports/reprints/ Storlazzi_W_1.pdf

Storlazzi CD, Logan JB, Field ME (2003) Quantitative morphology of a fringing reef tract from high-resolution laser bathymetry: southern Molokai, Hawaii. Geol Soc Am Bull 115:1344-1355

Szmant AM (2002) Nutrient enrichment on coral reefs: Is it a major cause of coral reef decline? Estuaries 25:743-766

Veron JEN (2000) Corals of the world. Australian Institute of Marine Science, Townsville

Vlasenko V, Hutter K (2002) Numerical experiments on the breaking of solitary internal waves over a slope-shelf topography. J Phys Oceanogr 32:1779-1793

Webster PJ, Moore AM, Loschnigg JP (1999) Coupled ocean-atmosphere dynamics in the Indian Ocean during 1997-98. Nature 401:356-360

> Wolanski E, Colin P, Naithani J, Deleersnijder E, Golbuu Y (2004) Large amplitude, leaky, island-generated, internal waves around Palau, Micronesia. Estuar Coast Shelf Sci 60:705-716

Wu G, Zhang Y (1998) Tibetan Plateau forcing and the timing of the monsoon onset over South Asia and the South China Sea. Bull Am Meteorol Soc 126:913-927

Submitted: July 27, 2010; Accepted: February 20, 2012

Proofs received from author(s): May 25, 2012 